Svitlana Krasynska*

\title{
Contra Spem Spero: The Third Sector's Resilience in the Face of Political Turbulence and Legislative Change in Ukraine
}

\begin{abstract}
The iconic Ukrainian poem, "Contra Spem Spero," with its theme of resilience in the face of enduring hardships, appears as salient for the Ukrainian people today as when it was composed more than a hundred years ago. Political instability and a far from favorable legislative system have affected Ukraine's society in a variety of ways since the dissolution of the Soviet Union. How have Ukraine's nongovernmental organizations (NGOs) been shaped by these conditions? A review of academic and applied literature, as well as governmental reports and legislative texts, reveals that the political and legislative environment in Ukraine is highly unstable and, at times, antagonistic to NGOs. However, indicators of sector activity and interviews with Ukrainian nonprofits suggest that the sector, overall, has not changed significantly during the last decade of substantial political and legislative changes. This paper suggests that Ukrainian nonprofits (much like Ukrainian society in general) appear to exist in a parallel universe with the governmental and legislative world. Ukrainian nonprofits are generally not supported by and are largely independent from the government. The concept of a shadow economy in Ukraine is discussed as a way of understanding how nonprofit organizations continue to function in what is often an adverse policy environment.
\end{abstract}

Keywords: Ukraine, third sector, nongovernmental organizations, political environment, legislation, shadow economy

DOI $10.1515 / \mathrm{npf}-2014-0003$

\section{Introduction}

Limited literature addresses the current state of Ukraine's third sector (Bebeshkina and Kaźmierkiewicz 2012; Palyvoda and Golota 2010; Stewart

“Contra Spem Spero” (1890), translated from Latin as “Against all Hope I Hope," is the title of a poem by one of Ukraine's most revered poets, Lesya Ukraïnka.

*Corresponding author: Svitlana Krasynska, School of Leadership and Education Sciences, University of San Diego, San Diego, CA, USA, E-mail: skrasynska@sandiego.edu 
2009; Kuts and Palyvoda 2006). Furthermore, despite the significant changes that have taken place in Ukraine's political and legislative environment during the last decade, no studies have specifically focused on the political and legislative factors affecting the sector and the environment in which it must function. This analytical essay pieces together information gleaned from academic literature produced by different disciplines, including political science, law, public administration, economics, sociology, and nonprofit research in an attempt to answer the following questions:

1. What is the current political and legislative environment for Ukraine's NGOs?

2. How has the third sector changed in response to this environment?

3. What factors are behind the sector's response to the current political and legislative conditions?

To supplement findings in the academic literature, the paper also focuses on governmental reports from the United States, the European Union, and Ukraine, along with practitioner publications and original texts of adopted and proposed laws. Finally, to make insights gathered from the literature more concrete and also to compensate for a possible Western bias in the literature, the paper reports on the results of semi-structured interviews with representatives of five Ukrainian NGOs of varied sizes, missions, funding sources, and organizational structures.

Throughout this essay, the author uses the terms nonprofits and nongovernmental organizations (NGO), as well as the third and the nonprofit sector, interchangeably. Entities discussed in this review encompass all organizations registered in Ukraine as either "public associations" or "charitable organizations" which are governed by various Ukrainian laws, including, most notably, the Law on Public Associations and the Law on Charitable Activities and Charitable Organizations. It is important to note that public associations dominate the sector; in 2009, they comprised 89 percent of Ukraine's NGOs, with the remaining 11 percent designated as charities (Palyvoda and Golota 2010, 22).

This essay focuses on three general topics that are discussed in the three major sections of the paper. The first section, The environment, provides an overview of current political and legislative conditions, as well current economic factors that influence NGOs in Ukraine. The second section, The third sector, attempts to assess Ukraine's third sector's reaction to political, legislative, and economic changes by exploring longitudinal nonprofit sector statistics enriched by key finding from interviews with several Ukrainian NGOs. The last section, Resilience and the shadow economy, attempts to make sense of the apparent 
anomaly that appears when the current state of NGOs in Ukraine is compared to the information about the political and legislative environment. The paper concludes with policy implications and recommendations for future research.

\section{The environment}

\section{Political conditions}

Ukraine's political environment has been consistently volatile since the country gained its independence from the Soviet Union. This section reviews insights from the literature about this volatility in the last decade, though the civic protests that began in November 2013, commonly known as EuroMaidan, are not discussed. These processes were ongoing, and their results still uncertain, at the time this essay was written. They do, however, provide further evidence about a major theme that will be developed in this first section: the unstable nature of the political environment in Ukraine.

\section{The Orange Revolution and its aftermath}

After the 2004-2005 massive public protests known as the Orange Revolution, Ukraine experienced positive developments in terms of the promotion of academic, election, and media freedoms. Thus, as a result of the Orange Revolution, for the first time in its history, Ukraine received a "Free" status in terms of political rights and civil liberties by the Freedom House (2007). However, contrary to popular expectations, levels of civic activity remained unaffected in the period that followed, and NGO-government cooperation has not improved significantly, despite several prominent civic activists entering the political arena (D’Anieri 2010; Stewart 2009). Furthermore, since the "orange" President, Viktor Yuschenko, had not been able to implement the promised economic and political reforms, government corruption, a less-than-impartial judicial system, economic stagnation, and political instability persisted during his 2005-2010 presidential term.

With the 2010 election of Yushchenko's 2004 presidential opponent, Viktor Yanukovych, Ukraine began experiencing increased authoritarian trends, leading to a political environment that was no more, and arguably even less, democratic than in the pre-2004 Ukraine (Kudelia 2012, 426). President Yanukovych's policies have "restrained civic freedoms, specifically mass media, right to assembly, and 
elections" (Riabchuk 2012, 445). For example 2010 marked the dissolution of Ukraine's National Commission for Freedom of Speech and Media Development, the National Commission for Strengthening Democracy and the Rule of Law, as well as the human rights monitoring department within the Ministry of Internal Affairs (Haran 2010, 3). Not surprisingly, Ukraine was downgraded back to "Partly-Free" status by Freedom House (2011).

\section{The political environment and Ukraine's third sector}

Ukraine's political environment as of 2013 posed multiple challenges for the country's third sector. Research demonstrates, for instance, that restricted media freedoms have a negative effect on public trust in NGOs in Eastern Europe and the former Soviet Union (Lee et al. 2012). Thus, restrictions on media freedoms in Ukraine may be contributing to the low levels of public confidence in the country's nonprofits. According to a 2013 sociological poll, only four and a half percent of Ukrainians "fully trust" NGOs, whereas 18 percent "fully mistrust” them (Razumkov Center 2013). By comparison, in the United States, even during 2003, which marked the lowest contemporary point in public confidence, 18 percent of population had "a great deal" of confidence in nonprofits and only seven percent had "none at all" (Light 2008, 2).

Corruption has been found "consistently and strongly associated with lower levels of NGO sustainability" in the post-Soviet Eastern Europe (Epperly and Lee 2013, 1). Thus, Ukraine's pervasive corruption levels (Transparency International 2012) continue to pose challenges for the development and viability of the country's nonprofit sector. Furthermore, a lack of independence in Ukraine's judicial system has potential implications for the third sector's ability to safeguard its legal rights in courts. Global Corruption Barometer indicates a score of 4.5 for Ukraine (on a scale of $1-5$, with 5 being "extremely corrupt") in terms of corruption levels in the judiciary (Transparency International 2013, 38).

Government cooperation with the third sector in Ukraine also has been problematic in the past decade. While dialogue between governmental and third sector organizations generally increased since the Orange Revolution (Palyvoda and Golota 2010, 11), the effectiveness of such communication and the level of actual collaboration continues to be problematic (Stewart 2009, 188). Additionally, since 2010, the relationship between Ukraine's third sector and the government has become increasingly strained, as exhibited by the government's unauthorized surveillance and attendance at civic gatherings, pressure on journalists, politicians, and activists, as well as the detention and questioning of civic leaders (U.S. State Department 2012). 
Because cooperation between governmental agencies and nonprofit organizations generally tends to be greater at the local rather than the central level (Palyvoda and Golota 2010, 51), the extensive centralization of government in Ukraine (Babinova 2011) also poses at least indirect challenges for Ukraine's third sector. While the 2010 Budget Code (effective 2011) generally improves the conditions for local government's autonomy (Instytut Mista 2010), in practice, local governmental agencies are influenced to a great degree by the central government. This influence results from the ambiguous legal definitions of municipal autonomy, as well as local governments' dependence on national budget allocations (Babinova 2011). Furthermore, political developments between 2010 and 2013 have demonstrated an increase in government centralization (Haran 2012, 61-62), and while the issue was being addressed by the interim government in early 2014, the developments' practical implications were still uncertain at the time this essay was written.

\section{Summary}

In short, the political environment in Ukraine has not been conducive to the healthy development of the country's third sector. The increased restrictions on rights of assembly and media, the proliferation of corruption, the lack of independent judiciary, and the general lack of government-NGO sector cooperation are some of the factors that would seem to be impediments to the effective functioning of Ukraine's nonprofit sector.

\section{The legislative environment}

Turbulent political conditions have produced a similarly volatile legislative environment and this, too, would appear to impact the functioning of Ukraine's nonprofits. The sector is highly regulated via numerous national laws and legislative provisions that specifically pertain to nonprofit organizations. To be sure, there have been positive recent developments in key pieces of legislation, as described further in this section. However, Ukraine's NGOs continue to face challenges, in large part because the legal system is complex and frequently changing, and often lacks governmental bodies to implement and enforce essential laws. The following discussion reviews some of the most recent and notable laws and legislative changes, as well as their implications for the country's third sector. 


\section{The Law on Public Associations}

The new Law on Public Associations (replacing the 1992 Law on Association of Citizens and its subsequent 15 amendments) became effective as of January 1 , 2013. It offers momentous improvements for the NGO sector, including significant simplification of registration processes, as well as the lifting of territorial restrictions on operating and the granting authorization to earn income (Law on Public Associations 2013). Overall, however, while the new law generally is welcomed by the international community and Ukraine's third sector stakeholders, confusion about its implementation persists, and the law's practical efficacy has yet to be determined.

\section{The Law on Charitable Activities and Charitable Organizations}

The new Law on Charitable Activities and Charitable Organizations, effective February 2013, likewise may prove to be a positive development for Ukraine's NGOs as, among other things, it streamlines the registration process, simplifies provisions for mandatory governance structures, eliminates geographic limitations on operating, and expands admissible fields of charitable activities. As is the case with the Law on Public Associations, however, questions remain regarding the law's practical implications and efficacy.

\section{The Law on Volunteering}

By contrast, the Law on Volunteering, adopted in 2011, has been extensively criticized for imposing significant limitations on activities of Ukraine's third sector (Lyah 2012). Most notably, the law specifies multiple restrictions on volunteering by youth which is problematic, as volunteers in Ukraine are predominantly students (Palyvoda and Golota 2010, 38). Most notably, while the law institutes numerous limitations, as well as legal and procedural requirements, to date there is no body to govern and oversee the law.

\section{The Tax Code}

Finally, worthy of note is the country's Tax Code which is restrictive both in terms of exemptions from income tax for nonprofits, as well as deductions for individual and corporate contributions to nonprofits (USAID 2012, 2-3). For 
instance, Tax Code provisions exempt only certain types of revenues from corporate income tax and, since 2011, only organizations registered as "charities” are exempted from the Value Added Tax (VAT). As noted earlier, only 11 percent of Ukrainian nonprofits are classified as charities. Additionally, the Tax Code allows for tax deductions on individual and corporate donations; in practice, however, these exemptions are difficult to obtain and are rarely utilized. The upshot is that there is little tax incentive in Ukraine to either form or to donate to an organization.

\section{Summary}

In short, Ukrainian legislation does offer some apparent legal provisions to support third sector organizations. In practice, however, significant implementation issues remain, not the least of which is the lack of governmental agencies to oversee implementation and compliance.

\section{Economic factors}

Amid the political and legislative changes discussed above, Ukraine has experienced adverse economic conditions which were exacerbated by the global recession. While not a major focus of this essay, economic conditions are noted here briefly for the purposes of providing context, since the impact of the economic recession on nonprofits has been documented in other contexts (Johnson 2011; McClean and Brouwer 2010; Salamon, Geller, and Spence 2009) and, almost certainly, has had an impact on the Ukrainian NGO environment. In particular, the economic recession in Ukraine has prompted a stagnation of the national economy, rising unemployment levels, increased household indebtedness and loan defaults, and growing poverty levels (Bojcun 2011, 499). Ukraine continued experiencing economic recession in 2013 (World Bank 2013), and at the beginning of 2014 the country's economy was nearing default (Cullinan and Jelenkovic 2014).

In addition to the general scarcity of domestic resources in view of the economic downturn, the nonprofit sector has been facing a progressive decline in foreign grants, both from governmental and private international sources (Palyvoda and Golota 2010). To illustrate, while in 2002, almost 70 percent of organizations were funded by international grants (Kuts and Palyvoda 2006, 37), in 2008, only 55 percent of organizations reported receiving foreign funding (Palyvoda and Golota 2010, 41). Despite this decline in international support, 
however, foreign funding still represented the largest contributor to Ukraine's nonprofit economy. The Ukrainian government, for example, contributed only to 36 percent of surveyed organizations (Palyvoda and Golota 2010, 41).

Given political and legislative, as well as economic, challenges to its environment, how has the nonprofit sector endured in the last decade? The following will delve into the status and development of the sector between 2002 and 2013.

\section{The third sector}

Limited empirical data are available on the state of Ukraine's nonprofit sector. The majority of the literature refers to two reports of third sector indicators: (1) Civil Society Organizations in Ukraine: The State and Dynamics (Palyvoda and Golota 2010) and (2) CIVICUS Civil Society Index Report for Ukraine (Kuts and Palyvoda 2006). Both reports were produced in part by the Counterpart Creative Center (CCC) in Ukraine. These two reports track changes in Ukraine's civil society sector between 2002 and 2009. This paper relies upon these studies' findings, supplemented with the most recent USAID $(2012,2013)$ NGO Sustainability Index reports for Ukraine.

\section{Sector indicators}

As of 2009, there were approximately 63,000 registered NGOs in Ukraine (Palyvoda and Golota 2010, 18). In 2012 the official register contained over 85,000 organizations, including charities and public associations (USAID 2012, 2). Nevertheless, it was estimated that only 3,000-4,000 of registered organizations were active in 2009 (Palyvoda and Golota 2010, 18). Considering Ukraine's 45.5 million population, the number of nonprofits per capita (approximately one active organization per over 10,000 people) is relatively low. In comparison, the estimated number of active nonprofits in the United States is 2.3 million (Blackwood, Roeger and Pettijohn 2012), which constitutes a ratio of roughly one nonprofit per 136 individuals.

While the number of registered organizations appears to have increased in the last several years, levels of paid staff and volunteering per organization appear to have decreased. The CCC report indicates that 48 percent of surveyed organizations had permanent staff in 2009; this compares to 58 percent with permanent staff in 2005, a figure that, itself, represented a decline from 64 percent in 2002 (Palyvoda and Golota 2010, 10-36). Notably, only 24 percent of surveyed 
organizations reported to have had permanent employees in 2012 (USAID 2012, 4). These data, however, provide neither the actual number nor the full-time equivalent hours, of employees engaged by the sector. Thus, it is difficult to estimate whether these indicators mean that the sector employment overall has declined, or whether the percentage of nonprofits with permanent employees has declined due to the increased number of actual nonprofits.

Furthermore, general levels of volunteering appear to have slightly declined: "69 percent of organizations polled by CCC in 2012 had volunteers, compared to 75 percent in 2010” (USAID 2012, 4). This slight decline in levels of volunteering may coincide with the restrictions imposed by the recently adopted Law on Volunteering discussed earlier. However, as the findings in the following section may suggest, this decline may be due to organizations simply not officially reporting their volunteers in order to avoid administrative hurdles.

Membership levels, on the other hand, have been relatively stable between 2009 and 2012: approximately 36 percent of organizations reported that their membership levels have increased; whereas nine percent reported that membership has decreased in both 2009 and 2012 polls (USAID 2012; Palyvoda and Golota 2010, 37). This is notable, as most NGOs in Ukraine (82 percent in 2012) are membership organizations (USAID 2012, 3).

Despite some significant political, legislative, and economic challenges, as described earlier in this paper, and notwithstanding changes in the employment and volunteering indicators, the CCC report has concluded that, overall, the third sector in Ukraine has remained relatively stable between 2002 and 2009 (Palyvoda and Golota 2010, 89). Likewise, political and economic downturns since 2010 do not appear to have significantly altered the overall NGO indicators (USAID 2012), and service provision levels have remained completely unchanged since 2003 (USAID 2013).

\section{Summary}

While official numbers of NGOs may be lower than those of some of Ukraine's neighboring countries to the west, the levels of nonprofit activity within Ukraine appear relatively stable in the face of constraining conditions.

\section{Insights from five Ukrainian NGOs}

To get a deeper perspective of the third sector in Ukraine, and also to compensate for any Western biases in the literature, five representatives from Ukrainian 
NGOs were interviewed in the process of preparing this paper. While by no means representative of the entire third sector in Ukraine, the five organizations included a diverse list of organizations in terms of geographical representation, nonprofit missions, and organizational structures. They comprised (1) a leading human rights organization in eastern Ukraine; (2) a small youth organization in southern Ukraine; (3) a prominent environmental advocacy organization in western Ukraine; (4) a grassroots community development organization in central Ukraine; and (5) a coalition of organizations in the country's capital. Due to the small number of nonprofits in the country, it is not possible to provide greater background information about these organizations without putting them at risk.

\section{Approach}

Interviews were semi-structured and were conducted via Skype or, in one instance, by telephone. The number of interviews per representative ranged from one to three; total interview time was between 60 and 110 minutes per individual.

Interviewees were asked about governance and organizational structures, mission and populations served, programs and services provided, as well as key successes and challenges the organizations faced in the last ten years and/or were facing at the moment. Questions probed about how these factors have changed in the past ten years and what prompted those changes. Conversations subsequently delved into funding sources and how changes in funding have affected each organization's mission and operations. Finally, questions asked about political issues, including the impact of specific laws and changes in legislation on their respective organizations.

\section{Results}

Interviews generally substantiated findings gathered from the review of the literature. Namely, participants conveyed that the political and legislative environment for nonprofits in Ukraine was less than favorable and highlighted the following issues: (1) the political system is corrupt and unpredictable; (2) cooperation with government at all levels (including government funding) is ineffective; and (3) the laws and administrative procedures are complex, convoluted, frequently changing and often inequitable. At the same time, interviews revealed that, by and large, the political and legislative changes have not had a profound effect on the NGOs whose representatives were interviewed, echoing conclusions conveyed in CCC and USAID reports. This 
was explained, in part, by the prevalent culture norm of working around governmental processes, both by nonprofits and by the general population.

For example, the Law on Volunteering, while causing controversy before and immediately after it was adopted, was eventually ignored by nonprofits, which began managing the volunteer force on an informal basis, without declaring volunteers officially. (As noted earlier, this reliance on an informal approach to volunteering could help explain the slight decline in volunteering that was reported between 2010 and 2012 by USAID (2012, 4).) The absence of a governmental agency designated to enforce and oversee the law's implementation reduced the risk of penalties for noncompliance. One participant commented: "The simple truth is that nobody paid attention to the law and everybody kept on surviving." Another interviewee concurred: "Formally, nothing has changed, but now there is just [potentially more hassle]."

A similar dynamic, but in reverse, was reported about aspects of the newly adopted, more favorable legislation. The Law on Public Associations, although not ideal, is widely considered an improvement over its predecessor. However, one participant reported that the agency's activities before and after the law's adoption with regard to geographic limitations on operating have remained unchanged; the only difference was that, since the law's adoption, that aspect of activities was now considered "technically" legitimate.

Interview participants have reported that the Tax Code in Ukraine was complex, burdensome, and inconsistent. The process of filing taxes, for example, requires quarterly visits to a local tax office, standing in long lines, attending multiple appointments, and submitting varying forms. Furthermore, while the larger organizations had resources for an accountant to be knowledgeable of and in compliance with these procedures, smaller organizations did not. The grassroots organization leader noted that, especially for small community-based organizations (for which this agency occasionally served as fiscal sponsor), it often was preferable to conduct a cash transaction than to be involved with the process. A 17 percent tax on monetary aid to individuals was also mentioned as a major issue and a deterrent for charitable organizations.

Ethical considerations did not appear to concern the interviewees. On the contrary, it was suggested that unless an organization worked around the political and legislative domain, it would not be able to survive. A representative of a large organization, for example, said: "Pay taxes and sleep peacefully on the bench [outdoors] - in other words, the taxation regulation is completely unfair. And I am not even talking about public administration.” Furthermore, while the more sophisticated organizations reported higher levels of awareness and knowledge of the changing legislation, smaller organizations reported unfamiliarity with the laws' provisions. A small organization leader reported 
needing legal consultation in order to learn about the practical implementation of new laws, but also noted that the organization did not have the resources to pay for such consultation. Another organization leader stated, "The problem is not the laws, the problem is in implementation of the laws - nobody knows how to implement them." On the other hand, four of the five participants mentioned that, at various times, their organizations participated in attempts to change legislation through advocacy initiatives.

In general, interviewees exhibited a willingness to comply with laws as long as they were reasonable. Additionally, they expressed an interest in creating equitable policies that would help their work rather than hinder it.

\section{Findings about funding}

How were these organizations funded? Only two of the five organizations interviewed have ever received funding from governmental institutions, and in both cases these were one-time municipal grants. The environmental organization, for instance, after completing one grant cycle, decided to never apply again, in view of undue and incomprehensible reporting requirements. The leader of the organization stated: "Problems we have experienced as result of this grant were greater than the eventual results of the project."

Four participant organizations, on the other hand, received and were heavily reliant on foreign funding, including from governmental and private institutions. This seemed to make these organizations rather independent of governmental processes in Ukraine. One organization leader, when approached to participate in an interview, conveyed: "I do not think I can help you very much, as I know nothing about the laws, and politics do not affect us. We are being funded completely by [the European Commission]." The grassroots organization, on the other hand, did not receive any foreign funding, but subsisted on small membership dues, modest and sporadic corporate support, and individual cash donations. It is notable that this organization was financially constrained to a great degree and had no permanent staff, unlike the other four participants that had better financial arrangements because of the foreign assistance. This grassroots organization was also the most affected by the economic downturn.

\section{Summary}

In short, neither the political environment nor changing legislation appears to have had a significant effect on the five nonprofits whose representatives were interviewed. Thus, the interview findings largely supported the quantitative data 
about the lack of dramatic changes in Ukraine's third sector found in CCC and USAID reports. The interview data, however, do suggest some of the reasons why there has been a lack of impact. The five NGOs have learned how to circumvent governmental requirements, and, in so doing, navigate through persistent change and uncertainty. In addition, for some organizations, the availability of foreign funding serves to cushion the nonprofit from the adversities of the immediate external environment.

Undoubtedly, however, these are only partial explanations for the resilience of Ukraine's nonprofit sector in the face of an often turbulent and frequently changing political and legislative environment. The next and final section describes a deeper cultural reason for the resilience of Ukraine's nonprofit sector in troubled times.

\section{Resilience and the shadow economy}

This section, though tethered to literature whenever possible, is more speculative than the previous sections. The author argues here that there is a proliferation of an informal, or a shadow, economy in Ukraine, the existence of which helps explain the lack of change in the NGO sector despite dramatic changes in the political and legislative environment (changes that were undoubtedly compounded by global economic recession).

Before delving into the discussion of findings, a note of this paper's limitations is in order. The majority of literature referenced in this manuscript, for example, was written and/or published in the English-speaking academic and practitioner domains. A thorough assessment of Ukraine's third sector trends and dynamics within the current political and legislative environment would require a comprehensive review of empirical, theoretic and applied literature developed and published in Ukraine. Such texts are difficult to access in the amalgamated U.S. library databases or online sources, however, and thus are referenced here sparsely. As has already been noted, interviews were conducted with Ukrainian NGO representatives largely to compensate for the limitations of the literature reviewed and the Western bias that might be embedded in that literature.

\section{The shadow economy}

The informal, or shadow, economy is conducted under the official radar and is largely unregulated by the government. Definitions of it vary, however, components may include: (1) self-employment in informal enterprises or wage 
employment in informal jobs (Alter Chen 2005); (2) market-based production of goods and services deliberately concealed from public authorities (Schneider, Buehn, and Montenegro 2011); and (3) economic activities performed in communities based on relationships of kinship or friendship (Dallago 1990). Although impossible to measure precisely, it is estimated that the shadow economy in Ukraine constitutes at least 47 percent of the Growth Domestic Product (GDP), which is among the highest found in East European transition countries (Schneider, Buehn, and Montenegro 2011, 34).

In Ukraine, where the informal economy constitutes roughly half of the GDP, it seems virtually axiomatic that there is a sizable amount of informal activity also in the third sector, and interviews with five NGO representatives alluded to this supposition. Furthermore, a 2006 survey revealed that almost 50 percent (49.3) of Ukrainians provided support outside of formal nonprofit organizations, while only slightly more than eight percent (8.3) reported participating in an NGO (Kuts and Palyvoda 2006, 28).

\section{The state and society}

Prevalence of informal activities reflects the relationship dynamic between the state and society. Literature supports the notion that Ukrainian people tend to strive for limited contact with the government and pay as few taxes as possible to a government that provides limited protection (Kuzio 2012, 430). Looking at Ukrainian citizens' tax compliance, Berenson (2010) asserts: “Ukrainians are especially willing to hide their incomes and, perhaps, even seek to avoid contact with the state as much as possible" (Berenson 2010, 213). The author further stresses that not only do Ukrainians have extremely low levels of "attitudinal support for tax compliance..., but Ukrainians' trust in their state to do what is right as well as to fulfill its obligations as citizens was so low that it was almost nonexistent” (Berenson 2010, 214).

Thus, it would not be surprising if third sector organizations, which are largely comprised of people who have been engaged for over two decades in surviving and functioning amidst constant political and legislative instability, would attempt to circumvent unfavorable governmental procedures whenever possible. The five NGO representatives interviewed each alluded, albeit in somewhat different ways, to their organizations utilizing this practice. The head of the grassroots nonprofit, for example, said:

Eventually, it became apparent that, if you want to accomplish something, it is best not to bother with these complications [of formalizing nonprofit activity and seeking foreign 
funding] ...but to find a few resourceful people, unite with them, ask for a meager amount of cash from a business person, and then you can really do something. In other words, organizations doing work that is systemic, ... regulated and in compliance with the law are not that numerous.

Despite the examples presented above, at this point, evidence of an actual "shadow" third sector is still relatively sparse. The remainder of this section explores what such a third sector might look like and considers the type of research needed to document the existence of an informal Ukrainian third sector empirically.

\section{A "shadow" third sector?}

What are the implications of the societal prevalence of informal activity for the nonprofit sector? One implication is that, if there is a vital informal third sector operating in Ukraine, focusing exclusively on formal (predominantly foreignfunded) NGOs will only tell part - and, possibly, only a small part - of the story. Alternatively, being able to at least estimate the informal activity may enable researchers, practitioners, and policy-makers to see a different story about the third sector in Ukraine.

Such story would answer a range of questions that are presently not asked: What is the extent of informal civic, charitable, and philanthropic activity in Ukraine, and how does this activity relate to the formal NGO sector? How much of the informal activity is conducted in tandem with the sector and how much occurs completely outside of it? Most importantly, how are formal third sector organizations affected by this dynamic and what conditions would enable the formal sector to capitalize on the existence of extensive informal activity?

Additionally, an important question for future research is: What is the role of foreign funding in the proliferation of the informal sector? While a subject of a separate paper, it is worthy of note here that there is an emerging body of literature on the potentially negative influence of foreign funding on the development of local community-based organizations and civil society in developing economies (see, for example, Chahim and Prakash 2014; Burger and Owens 2013; Henderson 2000; and others) that could help elucidate some of the questions listed above.

Documenting the existence of an informal third sector may be difficult, and measuring the informal sector's extent and impact may present an even greater challenge. In the United States, for example, it is difficult to account for - and sometimes even locate - grassroots groups. Still, when a shadow economy operates in the larger society as extensively as it does in Ukraine, how this 
phenomenon plays out in the nonprofit sector needs to be explored despite the methodological challenges of such exploration. Hussmanns, for example, asserts that the development of informal economy statistics for the society, as whole, is "needed as an evidence-based tool for research and policy-making" (Hussmanns 2004, iii), and the same argument could be made for the third sector-related informal giving and volunteering.

The vital question is how to gather such data. Smith, argues that a starting point would be to treat voluntary grassroots organizations (and presumably informal economy practices, in general) as a separate sector of society, as the difference between these and more established organizations, such as the Smithsonian Institution or Harvard University in the United States, for instance, is simply too vast (Smith 2000, 244). Of course, such action represents merely a first step in documenting the extent - and influence - of a shadow third sector. The qualitative interview methods used in a limited way in this paper may be a next step. It could be followed by survey studies that attempt to assess the generalizability of results generated from the smaller samples that qualitative interview studies normally employ. The potential pitfalls of conducting a largescale survey study in a country like Ukraine, however, are rather obvious. Still, unless the informal sector is studied in-depth, our understanding of Ukraine's third sector may be deficient. Furthermore, the reasons for the sector's apparent immunity to the dramatic changes in the political, legislative, and economic landscape in Ukraine may not be as evident.

\section{Conclusions}

This paper used existing literature to document the political, legislative, and economic upheaval that has occurred in Ukrainian society over the past decade. The paper's findings also suggest that Ukraine's third sector has not changed dramatically during the same period of time, despite the often dramatic changes that have occurred in the political and legislative domains, compounded by significant economic downturns. Data from interviews with representatives of five quite different NGOs tended to reinforce the storyline suggested by the information gathered from the literature. Additionally, interview results provide at least a partial explanation for why the nonprofit sector exhibited relatively limited change despite rather dramatic changes in the external environment. The interviewees' responses suggested that there may be an informal, or a shadow third sector, just as there is a sizable shadow economy in the country. This informal third sector economy in Ukraine, at times, operates independent of formal third sector organizations and, at other times, operates within the formal 
sector. The paper briefly discussed how this shadow version of the third sector might be studied.

The paper's conclusions have rather interesting policy implications. If there is a shadow third sector, as the interviewees seem to suggest, there are also informal policies that presumably could compete with formal policies in Ukraine. Certainly, that is the message that each of the interviewees appeared to deliver. There are also questions about what policies might bring the shadow sector out of the shadows and whether adopting such policies would be wise in a political environment as treacherous as the one in Ukraine.

Finally, there is a pressing need for a research agenda that would include a systematic empirical and theoretic exploration of the informal nonprofit activity in Ukraine. It should include: (1) assessing the extent and impact of informal nonprofit and philanthropic activities in Ukraine, as well as forces and logics behind them; (2) understanding intersection and interaction of Ukraine's formal and informal sectors and, possibly, how one may inform and augment the other; (3) exploring what roles domestic governmental and foreign funding play in these dynamics; and (4) contributing to the ongoing research on the role of civil society, and nonprofit organizations in particular, in civic and political processes, pondering the long-debated question of the weakness (or strength) of Ukraine's civil society (D’Anieri 2010; Howard 2003).

The proposed research agenda may shed light on some of the conundrums faced by development professionals, as well as third sector researchers and policy-makers, in other post-socialists settings. There is a pressing need for such research, as it is becoming increasingly clear that Western concepts of nonprofit organizations, civil society, and philanthropy do not universally apply in Eastern Europe.

\section{References}

Alter Chen, M. 2005. Rethinking the Informal Economy: Linkages with the Formal Economy and the Formal Regulatory Environment. Research Paper, UNU-WIDER, United Nations University (UNU), No. 2005/10. http://hdl.handle.net/10419/63329

Babinova, 0. 2011. "Local Self-Government in Ukraine: Strategic Priorities and Problems of Realization". Journal of Public Administration and Policy Research 3(4):98-105.

Bekeshkina, I., and P. Kaźmierkiewicz. 2012. “Making Ukraine’s Civil Society Matter: Enabling Ukrainian NGOs to absorb international assistance." A review of capacity gaps and needs for institutional support. Warsaw, Poland: Institute of Public Affairs. Accessed on December 28, 2013. http://www.isp.org.pl/uploads/pdf/1965036503.pdf

Berenson, M. 2010. "Less Fear, Little Trust: Deciphering the Whys of Ukrainian Tax Compliance." In Orange Revolution and Aftermath: Mobilization, Apathy, and the State in Ukraine, edited by P. D’Anieri, 193-228. Washington, DC: Woodrow Wilson Center Press. 
Blackwood, A. S., K. L. Roeger, and S. L. Pettijohn. The Nonprofit Sector in Brief: Public Charities, Giving, and Volunteering, 2012. Urban Institute. Accessed on October 28, 2013. http://www.urban.org/UploadedPDF/412674-The-Nonprofit-Sector-in-Brief.pdf

Bojcun, M. 2011. "The International Economic Crisis and the 2010 Presidential Elections in Ukraine. Journal of Communist Studies and Transition Politics 27(3-4):496-519.

Burger, R., and T. Owens. 2013. "Receive Grants or Perish? the Survival Prospects of Ugandan Non-Governmental Organisations." The Journal of Development Studies 49(9):1284-98.

Chahim, D., and A. Prakash. 2014. "NGOization, Foreign Funding, and the Nicaraguan Civil Society." Voluntas 25(2):487-513.

Cullinan, T., and A. Jelenkovich. (2014). "Ukraine Foreign Currency Rating Lowered to 'CCC' on Escalation of Political Turmoil; Outlook Negative.” Standard \& Poor's Ratings Services, Ratings Direct, February 21, 2014, Accessed on September 13, 2014. http://www. standardandpoors.com/spf/upload/Events_US/4214_art2.pdf

Dallago, B. 1990. The Irregular Economy: The "Underground" Economy and the "Black" Labour Market. Aldershot, Hants: Dartmouth.

D'Anieri, P. ed. 2010. Orange Revolution and Aftermath: Mobilization, Apathy, and the State in Ukraine. Washington, DC: Woodrow Wilson Center Press.

Epperly, B., and T. Lee. 2013. "Corruption and NGO Sustainability: A Panel Study of PostCommunist States." VOLUNTAS: International Journal of Voluntary and Nonprofit Organizations 24. doi:10.1007/s11266-013-9404-3.

Freedom House. 2007-2013. "Freedom in the World.” Accessed December, 2013. http://www. freedomhouse.org/report-types/freedom-world\#.UtMtYfRDvBY

Haran, O. 2010. "Is the Yanukovych Model of Governance Drifting Toward Russian Shores?" PONARS Eurasia Policy Memo No. 121. PONARS Eurasia 2010. Accessed on October 15, 2013. http://www.spa.ukma.kiev.ua/pdfs/pepm_121.pdf

Haran, O. 2012. "Ukraine: Pluralism by Default, Revolution, Thermidor." Russian Politics and Law 50(4):51-72.

Henderson, S. 2000. “Importing Civil Society: Foreign Aid and the Women's Movement in Russia,." Demokratizatsiya 8(1):65-82.

Howard, M. M. 2003. The Weakness of Civil Society in Post-Communist Europe. New York: Cambridge University Press.

Hussmanns, R. 2004. Preface to Measuring the Informal Economy: From Employment in the Informal Sector to Informal Employment, i-iii. Working Paper No. 53. Geneva, Switzerland: International Labour Office.

Instytut Mista. 2010. Byudzhetnyj Kodeks Ukrainy (V Redaktzii Vid 08.07.2010) Novatzii Dlya Mistzevoho Samovryaduvannya [Budget Code of Ukraine (as of 07.08.2010) Innovations for Local Self-Government]. Accessed on October 26, 2013. http://www.city-institute.org/ index.php?option $=$ com_content $\&$ view $=$ article\&id=103\&ltemid $=164$

Johnson, D. L. 2011. “Untwisting Lifeline Nonprofits in the Economic Crisis.” Georgetown Journal of Poverty Law \& Policy 18(2):201-45.

Kudelia, S. 2012. "The Sources of Continuity and Change of Ukraine's Incomplete State." Communist and Post-Communist Studies 45(3-4):429-38.

Kuts, S., and L. Palyvoda. 2006. "Civil society in Ukraine: 'Driving engine or spare wheel for change?' CIVICUS Civil Society Index Report for Ukraine.” Kyiv, Ukraine: Center for Philanthropy and Counterpart Creative Center; Johannesburg, South Africa: CIVICUS, World Alliance for Citizen Participation 1-131. 
Kuzio, T. 2012. "Twenty Years as an Independent State: Ukraine's Ten Logical Inconsistencies." Communist and Post-Communist Studies 45(3-4):429-38.

Law on Charitable Activities and Charitable Organizations, B.V.R., no. 25, st. 252 (2013)

(Ukraine). Accessed on August 15, 2013. http://zakon4.rada.gov.ua/laws/show/5073-17

Law on Public Associations, B.V.R., no. 1, pg. 1 (2013) (Ukraine). Accessed on March 10, 2013. http://zakon2.rada.gov.ua/laws/show/4572-17

Law on Volunteering, B.V.R., no. 42, st. 435 (2011) (Ukraine). Accessed on March 10, 2013. http://zakon2.rada.gov.ua/laws/show/3236-17

Lee, T., E. Johnson, and A. Prakash. 2012. "Media Independence and Trust in NGOs the Case of Postcommunist Countries." Nonprofit and Voluntary Sector Quarterly 41:8-35. doi:10.1177/0899764010384444.

Light, P. C. 2008. How Americans View Charities: A Report on Charitable Confidence, 2008. Washington, DC: Brookings Institution. https://wagner.nyu.edu/files/faculty/ publications/04_nonprofits_light.pdf

Lyah, T. L. 2012. Analiz Zakonu Ukrainy “Pro Volonters'ku Diyal'nist”" [Analysis of Ukraine's Law on Volunteering]. Kyiv, Ukraine: Coordination Council on the Development of Civil Society at the Office of the President of Ukraine. Accessed on March 10, 2013. http://civil-rada.in.ua/?p=860

McClean, C., and C. Brouwer. 2010. The Effect of the Economy on the Nonprofit Sector: A June 2010 Survey. Accessed on May 18, 2013. GuideStar USA. http://www.guidestar.org/ ViewCmsFile.aspx?ContentID $=2963$

Office of the President of Ukraine. 2012. “Ukaz Prezydenta Ukrainy № 212/2012: Pro strategiyu derzhavnoyi polityky spryiannya rozvytku hromadyans'koho suspil'stva $v$ Ukraini ta pershochergovi zahody ii realizatzii." Presidential Decree approved on March 24. http://www. president.gov.ua/documents/14621.html

Ogreba, S. 2013. "International Experience of Statistical Assessment of the Shadow Economy." Journal of Social Sciences 1(2):95-102.

Palyvoda, L., and S. Golota. 2010. Civil Society Organizations in Ukraine. The State and Dynamics (2002-2009): Survey Report 1-110. Kyiv, Ukraine: Publishing House "Kupol."

Razumkov Center. 2013. “Do You Trust Non-Governmental Organizations?” Accessed on August 22, 2013. http://www.razumkov.org.ua/eng/poll.php?poll_id=81

Riabchuk, M. 2012. “Ukraine’s ‘Muddling Through’: National Identity and Postcommunist Transition." Communist and Post-Communist Studies 45(3-4):439-46.

Salamon, L. M., S. L. Geller, and K. L. Spence. 2009. Impact of the 2007-09 Economic Recession on Nonprofits. The Johns Hopkins Listening Post Project Communiqué no. 14, Baltimore, MD: John Hopkins University Center for Civil Society Studies.

Schneider, F., A. Buehn, and C. E. Montenegro. 2011. "Shadow Economies All Over the World: New Estimates for 162 Countries from 1999 to 2007." In Handbook on the Shadow Economy, edited by F. Schneider, 9-77. Cheltenham: Edward Elgar.

Smith, D.H. 2000. Grassroots Associations. Thousand Oaks, CA: Sage Publications, Inc.

Stewart, S. 2009. "NGO Development in Ukraine Since the Orange Revolution." In Ukraine on Its Way to Europe: Interim Results of the Orange Revolution, edited by J. Besters-Dilger, 177-94. Frankfurt, Germany: Peter Lang.

Transperency International. 2012. “Corruption by Country/Territory: Ukraine.” Accessed on October 14, 2013. http://www.transparency.org/country\#UKR

Transperency International. 2013. “Global Corruption Barometer 2013.” Report published on July 19, 2013. http://www.transparency.org/whatwedo/pub/global_corruption_barometer_2013 
USAID. 2012. The 2012 CSO Sustainability Index for Central and Eastern Europe and Eurasia: Ukraine. Accessed on July 14, 2013. http://www.usaid.gov/sites/default/files/documents/ 1863/UKR.pdf

USAID. 2013. The 2013 CSO Sustainability Index for Central and Eastern Europe and Eurasia. Accessed on September 17, 2014. http://www.usaid.gov/sites/default/files/documents/ 1863/EE_2013_CSOSI_FullReport.pdf

U.S. State Department. 2011. Country Reports on Human Rights Practices for 2011: Ukraine. Accessed on March 10, 2013. http://www.state.gov/documents/organization/186627.pdf

U.S. State Department. 2012. Ukraine 2012 Human Rights Report. Accessed on October 15, 2013. http://www.state.gov/documents/organization/204561.pdf

World Bank. 2013. Ukraine Economic Update (April 2, 2013). Washington, DC: The World Bank. Accessed on January 10, 2014. http://documents.worldbank.org/curated/en/2013/04/ 17524708/ukraine-economic-update-april-2-2013. 